\title{
Adrenarche and Puberty in Children with Classic Congenital Adrenal Hyperplasia due to 21-Hydroxylase Deficiency
}

\author{
Thomas M.K. Völkl ${ }^{a} \quad$ Lisa Öhl ${ }^{a} \quad$ Manfred Rauh ${ }^{a} \quad$ Christof Schöfl ${ }^{b}$ \\ Helmuth G. Dörra \\ a Division of Pediatric Endocrinology and Diabetology, Department of Pediatrics and Adolescent Medicine, and \\ ${ }^{b}$ Division of Endocrinology and Diabetology, First Department of Internal Medicine, Friedrich Alexander University \\ of Erlangen-Nuremberg, Erlangen-Nuremberg, Germany
}

\section{Key Words}

Congenital adrenal hyperplasia $\cdot 21$-Hydroxylase $\cdot$

Adrenarche, puberty

\begin{abstract}
There have been only a few studies on adrenarche in girls with classic congenital adrenal hyperplasia (CAH) showing that dehydroepiandrosterone sulfate (DHEAS) levels did not rise at the physiological age of adrenarche. Objective: Longitudinal analysis of serum DHEAS levels and Tanner stages in CAH children. Design: We studied $98 \mathrm{CAH}$ patients ( $52 \mathrm{fe}-$ males), aged between 1 month and 18.0 years. All patients had genetically proven classic CAH and received steroid substitution therapy. Results: Serum DHEAS levels did not differ between $\mathrm{CAH}$ children and healthy children from the age of 1 year until 5-6 years. Beginning at the age of 7-8 years, there was a continuous but blunted increase in DHEAS levels in CAH boys and girls compared to healthy children. There was no correlation of DHEAS levels with the genotype, glucocorticoid dosage, auxological data, or quality of metabolic control. Pubarche ( $\mathrm{PH} 2)$ as well as gonadarche $(\mathrm{G} 2)$ and thelarche (B2) occurred significantly earlier in CAH boys and girls than in the reference group, but timing of menarche
\end{abstract}

was normal. Conclusions: Pubarche and adrenarche are dissociated in classic CAH: earlier pubarche, gonadarche and thelarche, respectively, in both sexes contrast with the absence of typical adrenarche.

Copyright $\odot 2011$ S. Karger AG, Basel

\section{Introduction}

Congenital adrenal hyperplasia (CAH) due to 21-hydroxylase deficiency is associated with abnormally low cortisol and low (salt wasting, SW-CAH) or normal aldosterone (simple virilizing, SV-CAH) production $[1,2]$. Due to an intact feedback system with activation of the $\mathrm{CRH}-\mathrm{ACTH}$ axis, the production of androgens and steroid precursors prior to the enzyme defect is increased [1, 2]. Adequate substitution therapy with glucocorticoids and mineralocorticoids is a prerequisite in order to avoid short-term and/or long-term complications such as elec-

Parts of this study were presented at the 47th Annual Meeting of the European Society for Paediatric Endocrinology (ESPE), September 20-23, 2008, Istanbul, Turkey.

\section{KARGER}

Fax +41613061234 E-Mail karger@karger.ch www.karger.com (c) 2011 S. Karger AG, Basel

$1663-2818 / 11 / 0766-0400 \$ 38.00 / 0$

Accessible online at:

www.karger.com/hrp
Prof. Helmuth G. Dörr, MD, Division of Pediatric Endocrinology and Diabetology

Department of Pediatrics and Adolescent Medicine

Friedrich Alexander University of Erlangen-Nuremberg

Loschgestrasse 15, DE-91054 Erlangen (Germany)

Tel. +499131853 3732, E-Mail helmuth-guenther.doerr@uk-erlangen.de 
trolyte imbalances, addisonian crisis, accelerated bone maturation, short stature, hirsutism and virilization, decreased fertility, obesity, and hypertension [3-5].

There are contradictory reports on the onset and course of puberty in CAH. Earlier data show that the onset of puberty in treated patients is more or less normal $[6-8]$. However, these studies only report the onset of puberty, i.e. Tanner stages B2 or G2, and not their follow-up or pubic hair stages [6-8]. According to two recent papers, there is an earlier onset of pubarche and thelarche in treated children with classic CAH $[9,10]$, whereas timing of menarche is normal [10].

The increase in the secretion of dehydroepiandrosterone (DHEA) and its sulfate ester (DHEAS) typically at the age of 5-6 years reflects the development of the zona reticularis of the adrenal cortex and is called adrenarche [11]. The mechanisms that initiate adrenarche are not known in detail to date. However, the increase in 17,20-lyase activity, IGF-1, and insulin concentrations, and the nutritional status play a role besides $\mathrm{CRH}$ and $\mathrm{ACTH}[11$, 12]. Pubarche, the development of pubic hair, is the clinical sign of adrenarche. Both terms, pubarche and adrenarche, are usually used as synonyms, but a dissociation between pubarche and biochemical markers of adrenarche can occur, e.g. in girls with Turner syndrome [13]. The dichotomy whether DHEAS levels can serve as a measure of disease control or as a target for suppression by glucocorticoid therapy can be neglected, since in clinical practice, DHEAS levels are not used to measure disease control $[1,2]$. CAH children with poor metabolic control have for example high serum 17-hydroxyprogesterone (17-OHP) and urine pregnanetriol (PT) levels but normal or low serum DHEAS levels.

Only a few studies on adrenarche in children with classic CAH have found low serum DHEAS levels in wellcontrolled patients [14-17]. Despite blunted adrenarche, the onset of pubarche (PH2) in children with classic $\mathrm{CAH}$ was found to be earlier in females and males with both clinical forms than in controls with a significantly earlier onset in SV-CAH than in SW-CAH [10].

Besides the known hormonal effects as an androgen, recent studies show positive effects of DHEA on well-being and sexuality in adult females with adrenal insufficiency [18]. Binder et al. [19] reported that atrichia pubis vanishes and psychological well-being improves significantly by daily replacement with $25 \mathrm{mg}$ DHEA orally in adolescent girls with central adrenal insufficiency.

Hence, the aim of this retrospective, single-center, longitudinal study was to measure serum DHEAS levels in a large cohort of patients with classic $\mathrm{CAH}$ and to correlate the data with Tanner stages of puberty. We studied potential contributing factors like medication dosage, bone age, height, and various laboratory parameters such as serum 17-OHP levels and 24-hour urine PT excretion.

\section{Methods}

\section{Patients}

We included 98 Caucasian children and adolescents (46 males, 52 females), who presented regularly at our outpatient endocrine unit. All individuals had classic CAH with 21-hydroxylase deficiency (salt wasting, SW: $\mathrm{n}=79$; simple virilizing, SV: $\mathrm{n}=19$ ). The phenotype classification was based on clinical and hormonal criteria, and the diagnosis was confirmed in all patients with molecular genetic analyses by direct sequencing (after exclusion of deletions). The disease-causing mutations were divided into four mutation groups ( $0, A, B$, and D) as previously described by Speiser et al. [20] (online suppl. material 1, for all online suppl. material, see www.karger.com/doi/10.1159/000333696). All patients received glucocorticoid substitution/androgen-suppressive therapy with hydrocortisone (HC), prednisone (PR) or dexamethasone (DX). $\mathrm{HC}$ was given three times daily ( $\sim 50 \%$ of the daily dosage in the early morning, $25 \%$ at noon, and $25 \%$ in the evening); PR was given twice and DX once daily in the morning. 96 patients additionally received fludrocortisone (twice daily) due to mineralocorticoid insufficiency diagnosed based on elevated renin concentrations. The quality of therapy was monitored during follow-up visits every 3-6 months by clinical presentation, bone age (BA) acceleration and laboratory measurements according to current guidelines [21]. None of the patients included in this study showed signs of severe under- or overtreatment such as Cushing's syndrome, severe hirsutism, increasing clitoris length, or growth failure.

\section{Study Design}

The longitudinal data of all patients were retrospectively ascertained from patient charts and the digital in-house CAH database. Based on the 98 patients, data from a total of 1,047 patientyears were available (males 433 years, females 614 years). The average available follow-up interval was 10.7 years $\pm 5.05 \mathrm{SD}$, median 10 years, range $1-18$ years (males $9.41 \pm 5.29$ years, females $11.8 \pm 4.59$ years). The study was approved by our institutional review board. All subjects and parents gave their written informed consent/assent.

Standardized physical examination in our department included the measurement of height (Harpenden stadiometer), weight (without clothes, except underwear), and the assessment of pubertal status (Tanner stages). Height standard deviation scores (SDS) were calculated using German references [22]. Pubarche was defined as the appearance of pubic hair (PH2), whereas puberty was defined as Tanner stage B2 in girls (by inspection and palpation) and testicular sizes $>3 \mathrm{ml}(\mathrm{G} 2)$ in boys, respectively.

Equivalent $\mathrm{HC}$ dosages (eHC) were calculated for PR and DX (factors 4 and 30, respectively) [23]. BA was assessed by an experienced observer using the atlas method of Greulich \& Pyle, which has been found to be reliable for Central European children [24]. For the evaluation of the current status of skeletal maturation, we calculated the difference between $\mathrm{BA}$ and chronological age (CA) (BA delay, $\triangle \mathrm{BA}=\mathrm{BA}-\mathrm{CA}$ in years) $[4,23]$. 
Table 1. Detailed clinical and laboratory cohort data of the children with classic $\mathrm{CAH}$

\begin{tabular}{|c|c|c|c|}
\hline & Males, $\mathrm{n}=46$ & Females, $\mathrm{n}=52$ & \\
\hline & $\begin{array}{l}\text { mean } \pm \text { SD } \\
\text { median [quartiles] }\end{array}$ & $\begin{array}{l}\text { mean } \pm \text { SD } \\
\text { median [quartiles] }\end{array}$ & $\begin{array}{l}\text { male vs. } \\
\text { female }\end{array}$ \\
\hline $\begin{array}{l}\text { Age } \\
\text { years }\end{array}$ & $\begin{array}{l}8.68 \pm 5.15 \\
8.0[4.0,13]\end{array}$ & $\begin{array}{l}8.58 \pm 5.02 \\
8.0[4.0,12]\end{array}$ & ns \\
\hline $\begin{array}{l}\text { Height } \\
\text { SDS }\end{array}$ & $\begin{array}{l}0.32 \pm 1.72 \\
0.20[-0.80,1.3]\end{array}$ & $\begin{array}{l}-0.58 \pm 1.21 \\
-0.60[-1.4,0.30]\end{array}$ & $<0.0001$ \\
\hline $\begin{array}{l}\text { BMI } \\
\text { SDS }\end{array}$ & $\begin{array}{l}1.02 \pm 1.31 \\
1.07[0.19,1.8]\end{array}$ & $\begin{array}{l}0.78 \pm 1.29 \\
0.92[-0.12,1.7]\end{array}$ & ns \\
\hline $\begin{array}{l}\mathrm{eHC} \\
\mathrm{mg} / \mathrm{m}^{2} / \text { day }\end{array}$ & $\begin{array}{l}16.5 \pm 5.22 \\
15.4[12.8,19.4]\end{array}$ & $\begin{array}{l}14.7 \pm 5.15 \\
13.7[11.2,16.8]\end{array}$ & 0.0024 \\
\hline $\begin{array}{l}\Delta \mathrm{BA} \\
\text { years }\end{array}$ & $\begin{array}{l}1.73 \pm 2.19 \\
1.0[0.0,3.5]\end{array}$ & $\begin{array}{l}0.358 \pm 1.37 \\
0.10[-0.60,1.1]\end{array}$ & $<0.0001$ \\
\hline $\begin{array}{l}\text { DHEAS }_{\mathrm{a}} \\
\mathrm{ng} / \mathrm{ml}\end{array}$ & $\begin{array}{l}268 \pm 393 \\
100[29.6,349]^{*}\end{array}$ & $\begin{array}{l}135 \pm 236 \\
65[38.8,135]^{*}\end{array}$ & 0.0105 \\
\hline $\begin{array}{l}\text { DHEAS }_{\mathrm{r}} \\
\mathrm{ng} / \mathrm{ml}\end{array}$ & $\begin{array}{l}265 \pm 444 \\
100[17.0,338]^{*}\end{array}$ & $\begin{array}{l}146 \pm 421 \\
62[33,129]^{*}\end{array}$ & 0.0053 \\
\hline $\begin{array}{l}\text { 17-OHP } \\
\mathrm{ng} / \mathrm{ml}\end{array}$ & $\begin{array}{l}10.9 \pm 19.3 \\
3.50[1.39,12.8]\end{array}$ & $\begin{array}{l}11.8 \pm 35.8 \\
4.10[1.45,10.4]\end{array}$ & ns \\
\hline $\begin{array}{l}\text { PT } \\
\mu \mathrm{g} / \text { day }\end{array}$ & $\begin{array}{l}4,120 \pm 8,266 \\
1,572[478,4,239]\end{array}$ & $\begin{array}{l}1,765 \pm 1,953 \\
1,140[374,2,392]\end{array}$ & 0.0002 \\
\hline
\end{tabular}

* DHEAS Ds. DHEAS $_{\mathrm{r}}$ : not significantly different for both sexes for $\mathrm{p}<0.05$.

eHC = Equivalent hydrocortisone dosage; $\mathrm{BA}=$ bone age; DHEAS = dehydroepiandrosterone sulfate; index a = averaged; $\mathrm{r}=$ raw data $17-\mathrm{OHP}=$ serum 17 -hydroxyprogesterone; $\mathrm{PT}=24$ hour urine pregnanetriol; $\mathrm{ns}=$ not significant for $\mathrm{p}<0.05$. Conversion factors: DHEAS: $\mathrm{ng} / \mathrm{ml}$ to $\mathrm{nmol} / \mathrm{l}, 2.714 ; 17-\mathrm{OHP}: \mathrm{ng} / \mathrm{ml}$ to $\mathrm{nmol} / \mathrm{l}, 3.03$.

Blood sampling in the morning between 8 and 12 a.m. (approx. $10-14 \mathrm{~h}$ after the last dose of $\mathrm{HC} / \mathrm{PR}$ ) was performed for monitoring the therapy. Serum or plasma was then separated by centrifugation and stored at $-20^{\circ} \mathrm{C}$ until assay. In addition, the day before, patients had collected samples of 24-hour urine at home according to our in-house protocol.

\section{Laboratory Methods}

DHEAS was measured with a Cobas e411 analyzer using system reagents (Roche, Mannheim, Germany). Intra- and interassay coefficients of variation $(\mathrm{CV})$ were both below $7.0 \%$. The conversion factor of DHEAS from $\mathrm{ng} / \mathrm{ml}$ to $\mathrm{nmol} / \mathrm{l}$ is 2.714 .

Most of the serum 17-OHP levels (about 90\%) were determined with a commercial RIA (Diagnostics Systems Laboratories, Sinsheim, Germany). Intra- and interassay CV were below $8 \%$; sensitivity was $0.02 \mu \mathrm{g} / \mathrm{l}$. About $10 \%$ of all serum probes were measured with the new established LC-MS/MS method. Intraand interassay CV were below 10\%; the limit of detection was 0.05 $\mathrm{ng} / \mathrm{ml}$. The reliability of both assays was investigated and published elsewhere [25]. The conversion factor from $\mathrm{ng} / \mathrm{ml}$ to $\mathrm{nmol} / \mathrm{l}$ is 3.03. Levels of PT in specimens of urine collected during $24 \mathrm{~h}$ were simultaneously determined by isotope dilution/gas chromatography-mass spectrometry procedure. Intra- and interassay $\mathrm{CV}$ were $<10.0 \%$.

\section{Statistics}

In order to minimize normal variations of DHEAS and an overestimation of a single patient, values of 1 year of life of a single patient were averaged $\left(\right.$ DHEAS $_{a}$ ) for comparison with the clinical parameters age, height, weight, medication, and BA. For correlation analysis of DHEAS with 17-OHP and PT, the raw data of all variables were used $\left(\right.$ DHEAS $\left._{\mathrm{r}}\right)$.

Our own data on healthy Caucasian children $(n=425$, males $\mathrm{n}=227$ ) served as control group [25]. The detailed cohort data are (age, $\mathrm{n}, \mathrm{DHEAS}$ serum levels $\mathrm{ng} / \mathrm{ml}$ : median (quartiles)): Boys: 1 year, $\mathrm{n}=26,357(129,667), 2-4$ years, $\mathrm{n}=27,66(1,145), 5-6$ years, $\mathrm{n}=22,132(46,187), 7-8$ years, $\mathrm{n}=28,133(50,233), 9-10$ years, $\mathrm{n}=22,464(207,865), 11-12$ years, $\mathrm{n}=20,860(416,1,575), 13-14$ years, $\mathrm{n}=27,1,510$ (1,160, 1,870), 15-16 years, $\mathrm{n}=31,1,460(1,068$, $2,070)$, and $17-18$ years, $n=24,1,430(1,188,2,548)$. Girls: 1 year, $\mathrm{n}=24,246(92,500), 2-4$ years, $\mathrm{n}=19,3.6(1,73.5), 5-6$ years, $\mathrm{n}=21,57(10,163), 7-8$ years, $\mathrm{n}=20,343(205,436), 9-10$ years, $\mathrm{n}=21,444(240,602), 11-12$ years, $\mathrm{n}=28,463(260,1,248), 13-14$ years, $\mathrm{n}=27,1,020(628,1,630), 15-16$ years, $\mathrm{n}=20,1,610(553$, 2,635), and 17-18 years, $\mathrm{n}=18,1,435(925,2,090)$ [26] (online suppl. material 2).

The onset of Tanner stages and menarche was compared with published data from normal Caucasian children [27, 28], as performed elsewhere [13]. Gaussian distribution of the parameters was tested using the D'Agostino-Pearson omnibus normality test $(p>0.05)$. In order to compare each variable between genders, clinical forms (SV, SW), and other subgroups, the Mann-Whitney $\mathrm{U}$ test was used where appropriate. For the assessment of significant deviations from a hypothetical value, we employed the Wilcoxon signed rank test. In addition to linear regression analysis, Spearman $\left(r_{s}\right)$ correlation coefficients were assessed, since some variables were not distributed normally. All tests were performed two-tailed and a p $<0.05$ was considered to be significant. For calculation and presentation, we used GraphPad Prism ${ }^{\mathrm{TM}}$ software version 5.03

\section{Results}

\section{Patient Group}

The clinical data of the patients are given in table 1 . The detailed genetic groups were among males: $0: \mathrm{n}=17$ ( $\mathrm{n}=16$ salt wasting, SW), A: $\mathrm{n}=17(\mathrm{n}=16 \mathrm{SW}), \mathrm{B}: \mathrm{n}=8$ $(\mathrm{n}=6$ simple virilizing, SV), and $\mathrm{D}: \mathrm{n}=4$ (presented with $\mathrm{SW}, \mathrm{n}=3$, or $\mathrm{SV}, \mathrm{n}=1$, with no detectable mutation on the second allele), and among females: $0: n=22(n=21$ SW), A: $\mathrm{n}=18$ ( $\mathrm{n}=18 \mathrm{SW}), \mathrm{B}: \mathrm{n}=10(\mathrm{n}=8$ simple virilizing), and $\mathrm{D}: \mathrm{n}=2(\mathrm{SW}, \mathrm{n}=1 ; \mathrm{SV}, \mathrm{n}=1)$. 


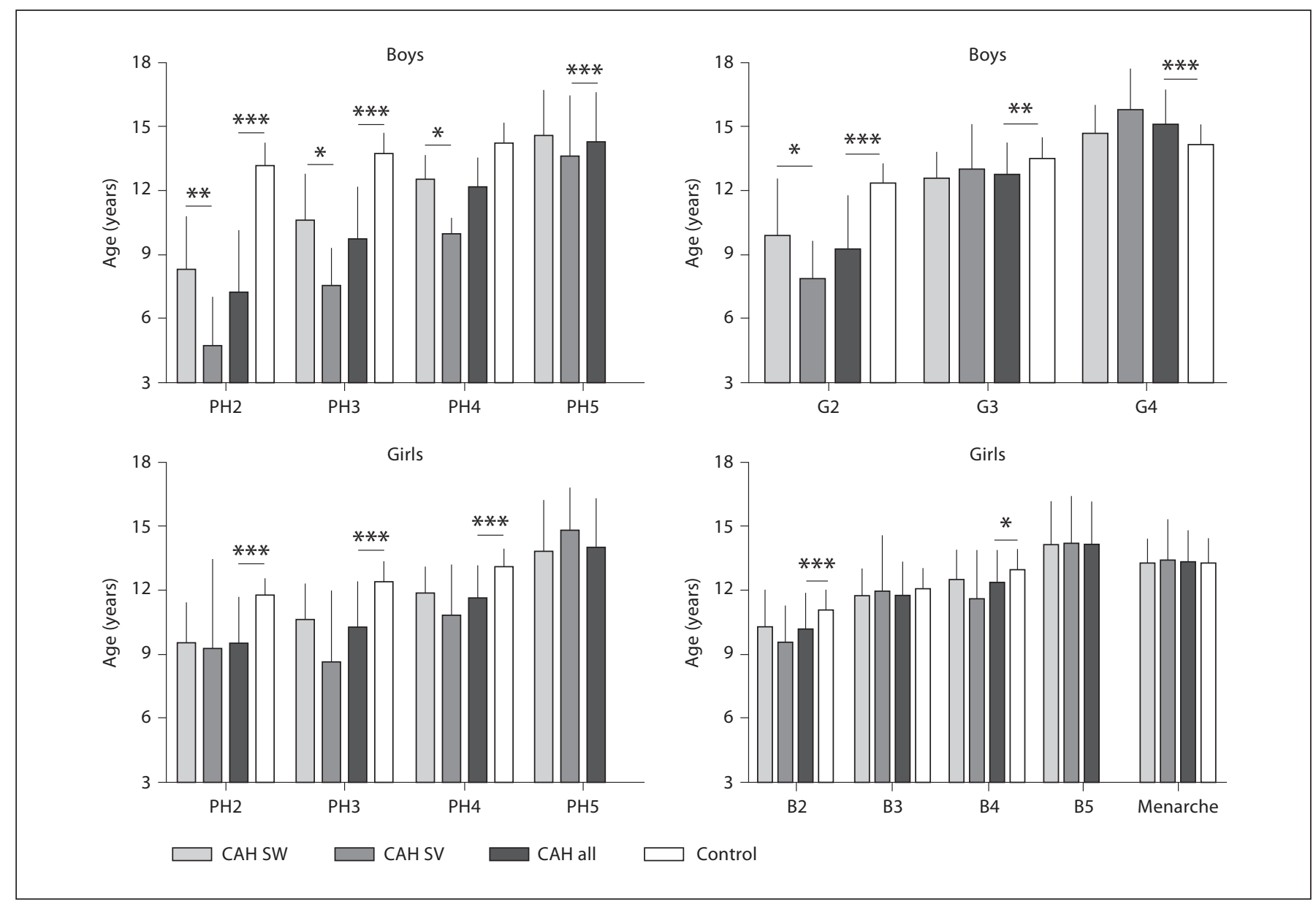

Fig. 1. Onset of Tanner stages. Upper panels: boys, pubic hair $(\mathrm{PH})$ and genital stage $(\mathrm{G})$. Lower panels: girls, $\mathrm{PH}$ and breast stages (B) with menarche. Shown are means with SD. Significance level is indicated by asterisks $\left({ }^{* * *} \mathrm{p}<0.001 ;{ }^{* *} \mathrm{p}<0.01{ }^{*} \mathrm{p}<0.05\right)$.

\section{Pubarche}

All Tanner stages of pubic hair (PH2 to $\mathrm{PH} 4)$ occurred significantly earlier in $\mathrm{CAH}$ children than in controls (mean \pm SD, CAH vs. controls; males: $\mathrm{PH} 2,7.2 \pm 2.9$ vs. $13.2 \pm 1.1$ years $(\mathrm{p}<0.001) ; \mathrm{PH} 3,9.7 \pm 2.5$ vs. $13.7 \pm 1.0$ years (p<0.001); PH4, $12.1 \pm 1.4$ vs. $14.3 \pm 0.9$ years ( $\mathrm{p}<0.001)$; PH5 $14.3 \pm 2.4$ years (no controls); females: $\mathrm{PH} 2,9.6 \pm 2.1$ vs. $11.8 \pm 1.0$ years $(\mathrm{p}<0.001)$; $\mathrm{PH} 3,10.3$ \pm 2.1 vs. $12.5 \pm 0.9$ years (p<0.001); $\mathrm{PH} 4,11.7 \pm 1.5$ vs. $13.2 \pm 0.9$ years $(\mathrm{p}<0.001)$; PH5 $14.1 \pm 2.3$ years (no controls); fig. 1).

A subgroup analysis between male SV and SW clinical forms is described below.

\section{Puberty}

Tanner stages G2 and G3 in boys occurred significantly earlier in $\mathrm{CAH}$ patients than in controls (mean $\pm \mathrm{SD}$,
CAH vs. controls; G2: $9.3 \pm 2.5$ vs. $12.4 \pm 0.92$ years $(\mathrm{p}<0.001) ; \mathrm{G} 3: 12.8 \pm 1.5$ vs. $13.6 \pm 1.0$ years $(\mathrm{p}<0.01))$, but G4 occurred significantly later (G4: $15.2 \pm 1.6$ vs. $14.3 \pm 0.88$ years $(\mathrm{p}<0.001)$; fig. 1$)$.

Breast stages and menarche in girls showed a different pattern, i.e. thelarche (B2) and Tanner stage B4 appeared significantly earlier in CAH girls, whereas B3 and menarche appeared at the same time as in the reference population (mean $\pm \mathrm{SD}, \mathrm{CAH}$ vs. controls; $\mathrm{B} 2$ : $10.3 \pm 1.6$ vs. $11.1 \pm 0.94$ years $(\mathrm{p}<0.001) ; \mathrm{B} 3: 11.8 \pm$ 1.6 vs. $12.1 \pm 0.95$ years ( $\mathrm{p}>0.05)$; $\mathrm{B} 4: 12.4 \pm 1.5$ vs. $13.0 \pm 0.95$ years $(\mathrm{p}<0.05)$; B5: $14.2 \pm 2.0$ years (no controls); menarche: $13.4 \pm 1.5$ vs. $13.4 \pm 1.1$ years ( $p>0.05$ ); fig. 1). In order to exclude that an earlier onset of B4 in CAH children was due to higher body weight and, accordingly, higher content of fat tissue of the breasts, we divided the B4 group into 'early' $(\leq 12.5$ 
Table 2. Correlations of serum DEHAS concentrations with different variables

\begin{tabular}{|c|c|c|c|c|c|c|}
\hline & \multicolumn{3}{|l|}{ Males } & \multicolumn{3}{|l|}{ Females } \\
\hline & $\mathrm{r}_{\mathrm{s}}(\mathrm{p})$ vs. DHEAS & $r_{s}(p)$ vs. age & $\mathrm{r}_{\mathrm{s}}(\mathrm{p})$ vs. 17-OHP & $\mathrm{r}_{\mathrm{s}}(\mathrm{p})$ vs. DHEAS & $\mathrm{r}_{\mathrm{s}}(\mathrm{p})$ vs. age & $\mathrm{r}_{\mathrm{s}}(\mathrm{p})$ vs. $17-\mathrm{OHP}$ \\
\hline \multicolumn{7}{|l|}{ DHEAS vs. } \\
\hline Age, years & $0.613(<0.0001)$ & 1 & & $0.378(<0.0001)$ & 1 & \\
\hline Height, SDS & ns & ns & & ns & ns & \\
\hline $\mathrm{eHC}, \mathrm{mg} / \mathrm{m}^{2} /$ day & $0.319(<0.0001)$ & $0.346(0.0001)$ & & $\mathrm{ns}$ & ns & \\
\hline$\Delta \mathrm{BA}$, years & $0.311(0.0003)$ & $0.357(<0.0001)$ & & $0.210(0.0001)$ & $0.186(0.0008)$ & \\
\hline 17-OHP, ng/ml & $0.411(<0.0001)$ & na & & $0.308(<0.0001)$ & na & \\
\hline PT, $\mu \mathrm{g} / \mathrm{day}$ & $0.504(<0.0001)$ & na & & $0.300(<0.0001)$ & na & \\
\hline \multicolumn{7}{|l|}{ 17-OHP vs. } \\
\hline $\mathrm{PT}, \mu \mathrm{g} / \mathrm{day}$ & & & $0.636(<0.0001)$ & & & $0.527(<0.0001)$ \\
\hline
\end{tabular}

years, $\mathrm{n}=12)$ and 'late' ( $>12.5$ years, $\mathrm{n}=7$ ) onset; however, the weight of both groups did not differ significantly (early onset $53 \pm 14$ vs. $56 \pm 13 \mathrm{~kg}$; BMI $1.24 \pm$ 0.34 SDS vs. $0.98 \pm 0.22$ SDS).

A subgroup analysis between male SV and SW clinical forms revealed that Tanner stages $\mathrm{PH} 2$ (SV vs. SW, mean $\pm \mathrm{SD} ; 4.7 \pm 2.3$ vs. $8.3 \pm 2.5$ years, $\mathrm{p}=0.009$ ), $\mathrm{PH} 3$ (SV vs. $\mathrm{SW}$, mean $\pm \mathrm{SD} ; 7.5 \pm 1.8$ vs. $10.6 \pm 2.2$ years, $\mathrm{p}=$ 0.0177 ), and PH4 (SV vs. SW, mean \pm SD, $10.0 \pm 0.71$ vs. $12.5 \pm 1.1$ years, $\mathrm{p}=0.0425$ ) occurred significantly earlier in male SV than in SW-CAH. There was no significant difference for PH4 and PH5. In terms of genital stages, a similar pattern was observed: G2 occurred earlier in SV than in SW-CAH (SV vs. SW, mean \pm SD $7.9 \pm 1.7$ vs. $10.0 \pm 2.6$ years, $\mathrm{p}=0.0425)$, but there was no significant difference for stages G3 and G4, respectively. Median age of diagnosis was within the first year of life, except for boys with SV-CAH (6.5 years).

In girls, the subgroup analysis between SV and SW clinical forms showed no significant difference for the age at different Tanner stages of pubic hair, breast development or menarche.

\section{Serum Dehydroepiandrosterone Sulfate (DHEAS)}

Serum DHEAS levels are shown in figure 2. Overall, boys and girls showed significantly lower DHEAS levels than the controls (boys from the CA of 5 years onwards and girls from the age of 7 years onwards, respectively). DHEAS levels during the first year of life were also significantly lower, i.e., the high neonatal levels of the con- trols were not found in (treated) CAH children. During infancy when zona reticularis was inactive, DHEAS levels did not differ from the controls.

In boys, an obvious increase in DHEAS levels was observed between ages 11 and 15 years, but thereafter DHEAS levels remained clearly below their healthy peers. Thus, correlation with age was significant $\left(r_{s}=0.613, p<\right.$ 0.0001 ; table 2). In contrast, girls showed a slight increase with age with a significant correlation compared to the controls $\left(\mathrm{r}_{\mathrm{s}}=0.378, \mathrm{p}<0.0001\right.$; table 2$)$, but adrenarche was not identified.

There was no significant correlation of DHEAS levels with height (table 2).

DHEAS and Clinical Forms (Salt Wasting, SW, vs.

Simple Virilizing, SV)

In boys, we found significantly higher DHEAS levels in SV than in SW. This is most probably due to the later age of diagnosis in boys with SV (median 6.5 years) compared to boys with SW, who were diagnosed during the first year of life (fig. 2). Additional analyses of different age groups in boys showed that DHEAS levels of SV boys were significantly higher from 3 to 14 years of age than in their SW peers: age group 3-6 years (median with quartiles, ng/ml): SV $230(29.5,336)$ vs. SW $30(10,100), \mathrm{p}=$ 0.0082; age group 7-10 years: SV $104(58.5,710)$ vs. SW 50 $(10.8,100), \mathrm{p}<0.0001$; age group 11-14 years: SV 349 (105, $543)$ vs. SW $178(63.5,288), \mathrm{p}=0.0308$; age group 15-18 years: SV $557(367,1,134)$ vs. SW $695(499,852), \mathrm{p}=0.8911$ (not significant). 


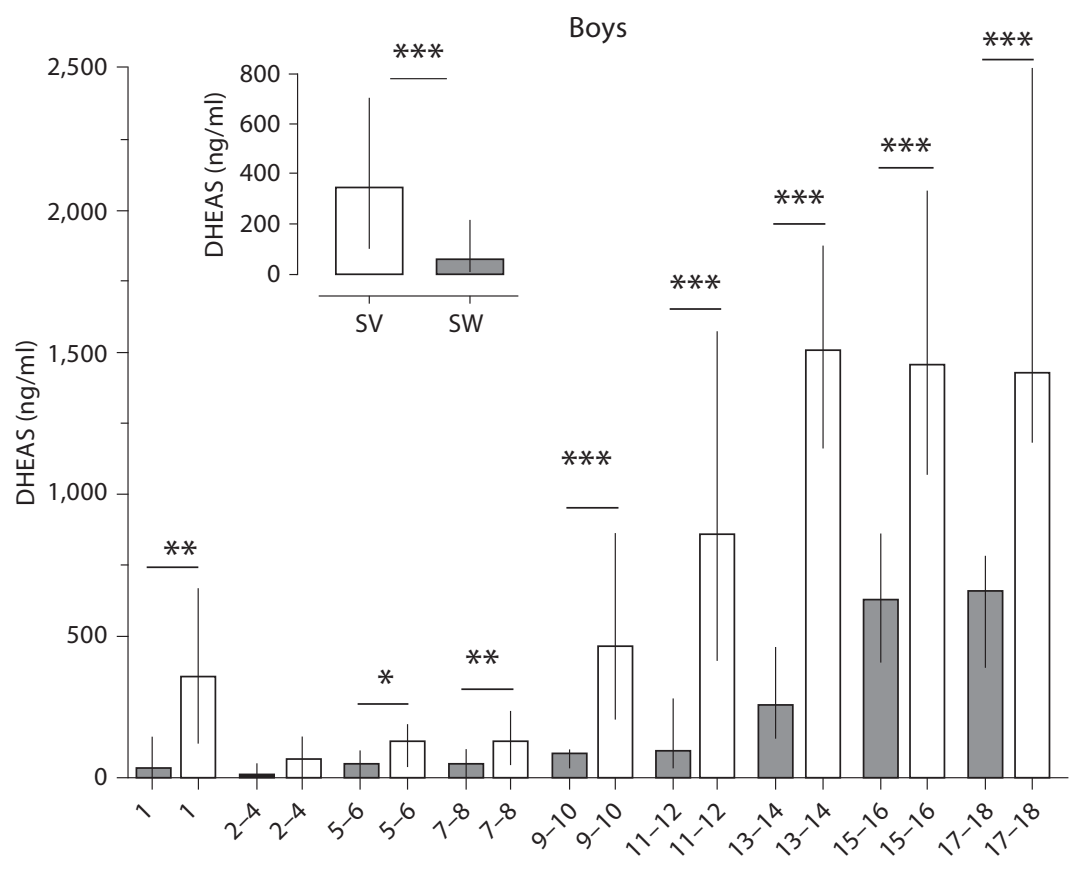

Age (years)

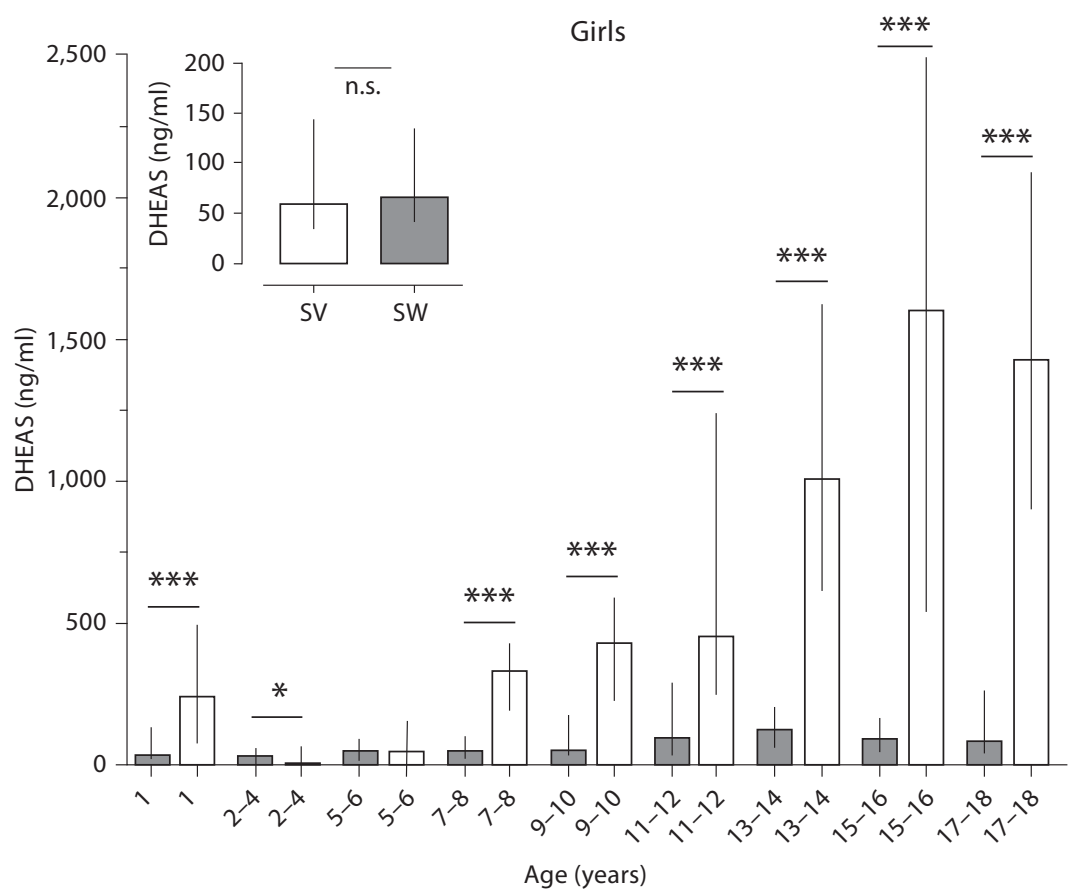

Fig. 2. Serum DHEAS levels in CAH (grey bars) boys (upper panel) and girls (lower panel) compared to controls (clear bars). Small panels show DHEAS levels among simple virilizing (clear bars) and salt-wasting (grey bars) subgroups of $\mathrm{CAH}$ children. Shown are medians with interquartile ranges. Significance level is indicated by asterisks $\left({ }^{* *} \mathrm{p}<0.001 ;{ }^{* *} \mathrm{p}<0.01{ }^{*} \mathrm{p}<0.05\right)$. 


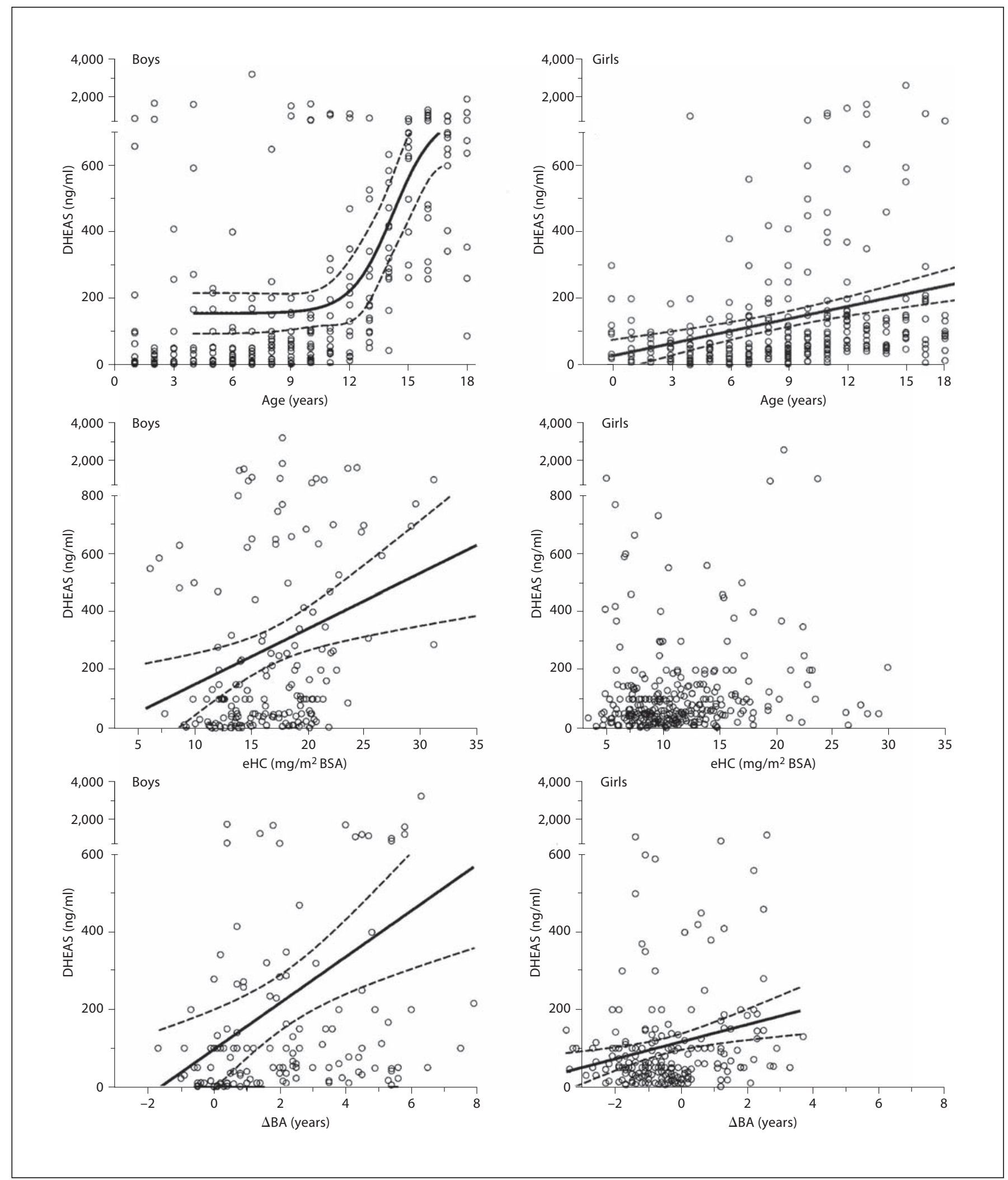

Fig. 3. Correlations of serum DHEAS levels with age, eHC, and $\triangle \mathrm{BA}(=\mathrm{BA}-\mathrm{CA})$ in boys (left panels) and girls (right panels). Shown are results of regression analyses with $95 \% \mathrm{CI}$. 
In contrast, there was no difference between both groups in girls, since the diagnosis was made early within both groups. SV girls were usually diagnosed due to their ambiguous genitalia (fig. 2).

\section{DHEAS and Metabolic Control}

Standard eHC dosages ranged between 6.1 and 32.6 $\mathrm{mg} / \mathrm{m}^{2} /$ day, the quartiles were 11.9 and $17.8 \mathrm{mg} / \mathrm{m}^{2} /$ day, respectively (table 1). DHEAS levels were positively correlated with eHC in boys $\left(\mathrm{r}_{\mathrm{s}}=0.319, \mathrm{p}<0.0001\right)$, but not in girls (table 2; fig. 3). Additionally, eHC levels were significantly correlated with age in boys $\left(\mathrm{r}_{\mathrm{s}}=0.346, \mathrm{p}<\right.$ $0.0001)$ and girls $\left(r_{s}=0.210, p<0.0001\right)$.

$\mathrm{BA}$, expressed as $\Delta \mathrm{BA}$, i.e. BA - CA, was significantly more advanced in boys than in girls (table 1). DHEAS was positively correlated with $\triangle \mathrm{BA}$ (boys: $\mathrm{r}_{\mathrm{s}}=0.311, \mathrm{p}=$ 0.0003; girls: $\left.r_{s}=0.210, p<0.0001\right)$ and also with CA (boys: $\mathrm{r}_{\mathrm{s}}=0.357, \mathrm{p}<0.0001$; girls: $\mathrm{r}_{\mathrm{s}}=0.200, \mathrm{p}<0.0001$; table 2; fig. 3).

Serum levels of 17-OHP were not significantly different between boys and girls (table 1). There was a positive correlation of DHEAS with 17-OHP levels among boys and girls; urinary levels of PT showed a similar pattern (table 2). Additionally, 17-OHP was positively correlated with PT in boys and girls (table 2).

\section{Discussion}

Our results from this retrospective, longitudinal single-center study provide evidence that pubarche and the following development of pubic hair arise earlier in girls and boys with $\mathrm{CAH}$, although serum levels of DHEAS are remarkably lower than controls in boys after adrenarche and tremendously reduced in girls, who do not show adrenarche at all.

There are some, mostly fragmentary, data on the onset and course of puberty in $\mathrm{CAH}$ patients in the literature, mainly within studies having another main topic, e.g. growth. Van der Kamp et al. [7] reported in CAH girls with salt-wasting Tanner stage B2 at ages $10.6 \pm 0.84$ years $(\mathrm{n}=12)$ and $10.4 \pm 1.3$ years $(\mathrm{n}=12)$ in 'non-salt wasters'; in CAH boys (SW) Tanner stage G2 (defined as testes volume $>3 \mathrm{ml})$ at age $11.8 \pm 1.5$ years $(\mathrm{n}=20)$ and $11.2 \pm 1.5$ years $(n=9)$ in 'non-salt wasters', respectively. Data on molecular genetics, especially of the 'non-saltwasting' group, were not available. Another retrospective analysis of patients with classic CAH of Canadian centers showed an average age of the onset of puberty defined as Tanner stage 2 of $10.4 \pm 1.6$ years $(\mathrm{n}=31)$ in girls and 11.1 \pm 2.1 years $(\mathrm{n}=23)$ in boys. The average age of menarche was $13.7 \pm 1.5$ years. No differentiation was made between clinical forms of CAH [8]. Balsamo et al. [6] studied a small number of CAH patients with SW (10 females, 8 males) and SV (10 females, 2 males). The occurrence of Tanner stages B2 and menarche was described at ages 11.9 \pm 1.4 years $(\mathrm{SW})$ and $9.6 \pm 1.6$ years $(\mathrm{SV})$ and $13.6 \pm$ 0.9 years (SW) and $12.7 \pm 1.3$ years (SV), respectively. Thelarche occurred significantly earlier in SV than in SW girls. In boys, Tanner stage G2 manifested itself at ages $10.5 \pm 1.5$ years $(\mathrm{SW})$ and $12.2 \pm 1.2(\mathrm{SV})$. Recently, Bonfig et al. [10] added data on pubarche (PH2) in classic CAH patients: in girls $8.2 \pm 1.2$ years $(\mathrm{SV}, \mathrm{n}=25)$ and 9.6 \pm 1.2 years (SW, $\mathrm{n}=32$ ). Thelarche (B2) occurred at ages $9.5 \pm 2.0$ years $(\mathrm{SV})$ and $10.3 \pm 1.4$ years $(\mathrm{SW})$. In boys, $\mathrm{PH} 2$ was reported at ages $7.4 \pm 3.5$ years $(\mathrm{SV}, \mathrm{n}=13)$ and $10.7 \pm 1.4$ years $(\mathrm{SW})$. Gonadarche (G2) occurred at ages $9.6 \pm 2.5$ years $(\mathrm{SV})$ and $11.0 \pm 1.3$ years $(\mathrm{SW})$. Both parameters differed significantly between SW and SV.

Our results add to these data by a longitudinal perspective of all Tanner stages compared to normal ranges. We found that pubarche and all other stages of pubic hair occurred earlier in CAH patients than in controls in general, and pubarche was earlier in boys with SV than in $\mathrm{SW}$, in particular. This is most likely due to a delayed diagnosis and start of therapy in SV boys, since the SV form in male neonates without newborn screening on $\mathrm{CAH}$ usually lacks obvious clinical signs. Therefore, the diagnosis of SV-CAH in boys within our cohort was made at a median age of 6.5 years. In agreement with Bonfig et al., this difference disappeared with higher $\mathrm{PH}$ stages. In contrast to Bonfig et al. [10], there was no difference in girls. Except for gonadarche (G2) in boys, there was no difference between Tanner stages B and G between SW and SV in girls and boys, respectively. Genital stages G2 and G3 occurred earlier, but G4 occurred later in boys, and stages B2 and B4 occurred later in girls, respectively. This is probably driven by an advanced BA as reported variously in $\mathrm{CAH}$, and more pronounced so in boys than in girls $[1,4,23,29,30]$. We speculate that earlier pubarche before gonadarche in girls and SW boys might be due to an incomplete androgen suppression in order to avoid glucocorticoid overtreatment. Therefore, low serum testosterone levels might accelerate BA maturation, earlier pubarche and subsequently earlier pubertal stages. In line with previous reports, the age at menarche was normal, and there was no difference between SW and SV [3, 31].

More than three decades ago, Korth-Schutz et al. [14] reported suppressed DHEA levels in 17 treated boys and 19 girls with classic $\mathrm{CAH}$. This result was confirmed lat- 
er by two independent studies measuring DHEAS levels: Brunelli et al. [15] reported data of $n=10 \mathrm{SW}$ and $n=6$ 'non-classic' CAH girls, aged between 3 and 12 years. DHEAS levels were lower than in the controls at all ages. There was a positive correlation between serum DHEAS and 17-OHP concentrations, although some girls showed high 17-OHP and low DHEAS levels at the same time. In 'non-classic' girls, DHEAS levels were much higher than in the controls at the time of diagnosis, but fell below the references in the further course of treatment. There was also a positive correlation with 17-OHP. The second study of 23 SW-CAH girls and 7 boys aged 5-20 years also reported reduced DHEAS levels in girls. More detailed statistics in boys could not be performed due to the small patient numbers [17]. Recent data of Argentinean girls showed similar results [16]. Our data in girls add to the current knowledge on the first year of life in girls, since DHEAS did not show the neonatal elevation found in controls because glucocorticoid therapy had already started and adrenal DHEAS production was suppressed. There was no difference between SW and SV clinical forms. In boys, serum DHEAS levels were also suppressed neonatally, but, in contrast to girls, there was a significant increase in concentration between ages 11 and 14 years, indicating some form of adrenarche. In line with earlier pubarche (PH2), DHEAS levels in SV were higher than in SW-CAH.

Adrenarche, which is defined as the significant increase of DHEA(S) production between ages 6 and 8 years, has been shown to be independent of gonadotrophins, ACTH, or functional gonads [12, 32-34]. Morphologically, there is evidence that the third adrenal zone, the zona reticularis (ZR), produces DHEA(S), starting its development around age 3 years $[12,35,36]$. Enzymatic studies show that StAR, the enzyme performing the first step of steroid hormone synthesis, is equally expressed in all zones of the adrenal [37]. The increased conversion of $17 \alpha$-hydroxypregnenolone to DHEAS results from an increase in 17,20-lyase activity, but also a decreased $3 \beta$ HSD activity, along with an increased activity of sulfotransferase (SULT2A1) [38]. This important step is regulated by multiple post-translational events [12]. Cytochrome b5 (CYB5), most evident in ZR, is an allosteric effector that interacts primarily with the oxidoreductase complex of CYP17 complex to stimulate 17,20-lyase activity. Its activity becomes more marked after age 5 years $[37,38]$. Another key enzyme of steroidogenesis, HSD3B2, competes with CYP17 for $17 \alpha$-hydroxyprogesterone. Therefore, low activity of HSD3B2 is crucial for sufficient DHEA production within the ZR [37, 39]. 21-Hydroxylase deficiency in CAH patients leads to increased C19 steroid production and androgen excess and decreased cortisol and aldosterone levels [1]. Under substitution therapy with $\mathrm{HC}$, this androgen excess is aimed to decline to normal levels [23]. During episodes of undertreatment, 17-OH-progesterone and testosterone levels are elevated, whereas the elevation of DHEAS concentrations, if present, is marginal. An exception to this is at the time of diagnosis of SV patients, who usually had a significant period of undetected disease, unless screened as newborns [15]. Interestingly, expression levels and immunohistochemical studies do not show differences of CYP21 among the different adrenal zones [12, 39]. A histological study of adrenals in $3 \mathrm{CAH}$ patients showed poorly defined zones of the cortex [40]. This might be evidence for insufficient genesis and functional development of the ZR in CAH. Since DHEAS levels are normal in patients with cortisol excess (Cushing's syndrome) [41] and DHEAS levels are high in untreated CAH patients [15], circulating cortisol seems to play no role within the context of the onset of adrenarche, as suggested several years ago [42].

In contrast, very recent data from cultured adrenal cells (COS-7) demonstrate that cortisol inhibits 3 $\beta-\mathrm{HSD} 2$ activity in cells transfected with HSD3B2. Thus, it is possible that intra-adrenal cortisol may participate in the regulation of adrenal DHEA secretion through inhibition of $3 \beta-H S D 2$ and contribute to the initiation of adrenarche [43].

Although it is clear that adrenarche is primarily associated with adrenocortical changes as described above, there is some evidence that hormones related to body mass, such as leptin, play a role in adrenal function. This might be a promising approach for future studies [4447]. In addition, defining adrenarche in CAH children is not possible, since they have low serum DHEAS levels. Thus, the transition from childhood to juvenility cannot be assigned exactly in CAH children [48].

The effectiveness of glucocorticoid substitution therapy, i.e. the metabolic control, over a period of several years is not easy to assess. Monitoring serum and urinary laboratory parameters cover only a few days or weeks, while advanced skeletal maturation as an index of poor metabolic control might be more representative over a longer period of time $[4,23]$. However, since multiple examiners ( $n=5$, all under supervision of H.G.D.) have performed pubertal staging, this might be a bias of our data. Interestingly, we found in our cohort a positive correlation of serum 17-OH-progesterone and urine PT levels with serum DHEAS levels, although DHEAS levels were 
below the normal range in older children of both sexes. A correlation of glucocorticoid dosage with DHEAS was not found in girls, but was in boys whose DHEAS and eHC levels were also correlated more strongly with age than in girls. This goes along with previously published data $[4,49]$. Therefore, externally administered steroids seem to play a minor dose-dependent role, which explains the lack of sufficient adrenarche in $\mathrm{CAH}$. However, for ethical reasons, any existing baseline effect cannot be analyzed in detail based on a study with untreated patients with classic CAH. In addition, BA is more advanced and mean PT is higher in male CAH patients. We speculate that (1) boys might be less compliant than girls and/ or the advanced BA in boys could be due to (2) the higher proportion of boys with late diagnosis of $\mathrm{CAH}(\mathrm{SV}$ $\mathrm{CAH}$ ) in our cohort.

In conclusion, we were able to show that pubarche and adrenarche are dissociated in classic $\mathrm{CAH}$ : earlier pubarche is found in treated children with classic CAH in both sexes, whereas typical adrenarche does not occur. There was no age-independent correlation of DHEAS levels with genotype, glucocorticoid dosage, auxological data or quality of metabolic control.

\section{Acknowledgements}

We greatly appreciate the technical assistance of Mrs. Jutta Biskupek-Sigwart.

This research did not receive any specific grant from any funding agency in the public, commercial or non-profit sector.

\section{Disclosure Statement}

T.M.K.V., L.Ö., C.S. and M.R. have nothing to declare. H.G.D. is member of KIGS' Germany Advisory Board and KIGS' International Board (Pfizer, less than USD 2,000 per year).

\section{References}

1 New MI: An update of congenital adrenal hyperplasia. Ann N Y Acad Sci 2004;1038: 14-43.

2 Merke DP, Bornstein SR: Congenital adrenal hyperplasia. Lancet 2005;365:2125-2136.

3 Otten BJ, Stikkelbroeck MM, Claahsen-van der Grinten HL, Hermus AR: Puberty and fertility in congenital adrenal hyperplasia. Endocr Dev 2005;8:54-66.

4 Völkl TMK, Simm D, Beier C, Dörr HG: Obesity among children and adolescents with classic congenital adrenal hyperplasia due to 21-hydroxylase deficiency. Pediatrics 2006;117:e98-e105.

5 Völkl TMK, Simm D, Dötsch J, Rascher W, Dörr HG: Altered 24-hour blood pressure profiles in children and adolescents with classic congenital adrenal hyperplasia due to 21-hydroxylase deficiency. J Clin Endocrinol Metab 2006;91:4888-4895.

6 Balsamo A, Cicognani A, Baldazzi L, Barbaro M, Baronio F, Gennari M, Bal M, Cassio A, Kontaxaki K, Cacciari E: CYP21 genotype, adult height, and pubertal development in 55 patients treated for 21-hydroxylase deficiency. J Clin Endocrinol Metab 2003;88: 5680-5688

7 Van der Kamp HJ, Otten BJ, Buitenweg N, De Muinck Keizer-Schrama SM, Oostdijk W, Jansen M, Emarre-de Waal HA, Vulsma T, Wit JM: Longitudinal analysis of growth and puberty in 21-hydroxylase deficiency patients. Arch Dis Child 2002;87:139-144.

8 Muirhead S, Sellers EA, Guyda H: Indicators of adult height outcome in classical 21-hydroxylase deficiency congenital adrenal hyperplasia. J Pediatr 2002;141:247-252.
9 Trinh L, Nimkarn S, New MI, Lin-Su K: Growth and pubertal characteristics in patients with congenital adrenal hyperplasia due to 21-hydroxylase deficiency. J Pediatr Endocrinol Metab 2007;20:883-891.

10 Bonfig W, Pozza SB, Schmidt H, Pagel P, Knorr D, Schwarz HP: Hydrocortisone dosing during puberty in patients with classical congenital adrenal hyperplasia: an evidencebased recommendation. J Clin Endocrinol Metab 2009;94:3882-3888.

11 Auchus RJ, Rainey WE: Adrenarche - physiology, biochemistry and human disease. Clin Endocrinol 2004;60:288-296.

12 Nakamura Y, Gang HX, Suzuki T, Sasano H, Rainey WE: Adrenal changes associated with adrenarche. Rev Endocr Metab Disord 2009;10:19-26.

13 Martin DD, Schweizer R, Schwarze CP, Elmlinger MW, Ranke MB, Binder G: The early dehydroepiandrosterone sulfate rise of adrenarche and the delay of pubarche indicate primary ovarian failure in Turner syndrome. J Clin Endocrinol Metab 2004;89:1164-1168.

14 Korth-Schutz S, Virdis R, Saenger P, Chow DM, Levine LS, New MI: Serum androgens as a continuing index of adequacy of treatment of congenital adrenal hyperplasia. J Clin Endocrinol Metab 1978;46:452-458.

15 Brunelli VL, Chiumello G, David M, Forest MG: Adrenarche does not occur in treated patients with congenital adrenal hyperplasia resulting from 21-hydroxylase deficiency. Clin Endocrinol (Oxf) 1995;42:461-466.
16 Guercio G, Rivarola MA, Chaler E, Maceiras M, Belgorosky A: Hydrocortisone treatment in girls with congenital adrenal hyperplasia inhibits serum dehydroepiandrosterone sulfate and affects the GH-IGF-I system. J Pediatr Endocrinol Metab 2009;22:255-261.

17 Sellers EP, MacGillivray MH: Blunted adrenarche in patients with classical congenital adrenal hyperplasia due to 21-hydroxylase deficiency. Endocr Res 1995;21:537-544.

18 Gurnell EM, Hunt PJ, Curran SE, Conway CL, Pullenayegum EM, Huppert FA, Compston JE, Herbert J, Chatterjee VK: Long-term DHEA replacement in primary adrenal insufficiency: a randomized, controlled trial. J Clin Endocrinol Metab 2008; 93:400-409.

19 Binder G, Weber S, Ehrismann M, Zaiser N, Meisner C, Ranke MB, Maier L, Wudy SA, Hartmann MF, Heinrich U, Bettendorf M, Dörr HG, Pfäffle RW, Keller E: Effects of dehydroepiandrosterone therapy on pubic hair growth and psychological well-being in adolescent girls and young women with central adrenal insufficiency: a double-blind, randomized, placebo-controlled phase III trial. J Clin Endocrinol Metab 2009;94:11821190

20 Speiser PW, Dupont J, Zhu D, Serrat J, Buegeleisen M, Tusie-Luna MT, Lesser M, New MI, White PC: Disease expression and molecular genotype in congenital adrenal hyperplasia due to 21-hydroxylase deficiency. J Clin Invest 1992;90:584-595. 
21 Clayton PE, Miller WL, Oberfield SE, Ritzen EM, Sippell WG, Speiser PW: Consensus statement on 21-hydroxylase deficiency from the European Society for Paediatric Endocrinology and the Lawson Wilkins Pediatric Endocrine Society. Horm Res 2002;58: 188-195.

22 Reinken L, Stolley H, Droese W, van Oost G: Longitudinal data of physical growth of healthy children. II. Height, weight, skinfold thickness of children aged 1.5-16 years. Klin Pädiatr 1980;192:25-33.

23 Hindmarsh PC: Management of the child with congenital adrenal hyperplasia. Best Pract Res Clin Endocrinol Metab 2009;23: 193-208.

24 Groell R, Lindbichler F, Riepl T, Gherra L, Roposch A, Fotter R: The reliability of bone age determination in central European children using the Greulich and Pyle method. $\mathrm{Br}$ J Radiol 1999;72:461-464.

25 Rauh M, Gröschl M, Rascher W, Dörr HG: Automated, fast and sensitive quantification of $17 \alpha$-hydroxy-progesterone, androstenedione and testosterone by tandem mass spectrometry with on-line extraction. Steroids 2006;71:450-458.

26 Frenzel S, Biskupek-Sigwart J, Breuning A, Dörr HG: Dehydroepiandrosteronsulfat (DHEAS) im Serum bei gesunden Kindern und Jugendlichen. Monatsschr Kinderheilkd 1997;145:100.

27 Buckler J: A Longitudinal Study of Adolescent Growth. London, Springer, 1990.

28 Kahl H, Schaffrath RA, Schlaud M: Sexual maturation of children and adolescents in Germany. Results of the German Health Interview and Examination Survey for Children and Adolescents (KiGGS) (in German). Bundesgesundheitsblatt Gesundheitsforschung Gesundheitsschutz 2007;50:677685.

29 Frisch H, Waldhauser F, Lebl J, Solyom J, Hargitai G, Kovacs J, Pribilincova Z, Krzisnik C, Battelino T: Congenital adrenal hyperplasia: lessons from a multinational study. Horm Res 2002;57(suppl 2):95-101.

30 Hoepffner W, Kaufhold A, Willgerodt H, Keller E: Patients with classic congenital adrenal hyperplasia due to 21-hydroxylase deficiency can achieve their target height: the Leipzig experience. Horm Res 2008;70:4250.
31 Manoli I, Kanaka-Gantenbein C, Voutetakis A, Maniati-Christidi M, Dacou-Voutetakis C: Early growth, pubertal development, body mass index and final height of patients with congenital adrenal hyperplasia: factors influencing the outcome. Clin Endocrino (Oxf) 2002;57:669-676.

32 Sklar CA, Kaplan SL, Grumbach MM: Evidence for dissociation between adrenarche and gonadarche: studies in patients with idiopathic precocious puberty, gonadal dysgenesis, isolated gonadotropin deficiency, and constitutionally delayed growth and adolescence. J Clin Endocrinol Metab 1980;51: 548-556.

33 Genazzani AR, Facchinetti F, Petraglia F, Pintor C, Bagnoli F, Puggioni R, Corda R: Correlations between plasma levels of opioid peptides and adrenal androgens in prepuberty and puberty. J Steroid Biochem 1983; 19:891-895.

34 Genazzani AR, Facchinetti F, Pintor C, Puggioni R, Parrini D, Petraglia F, Bagnoli F, Corda R: Proopiocortin-related peptide plasma levels throughout prepuberty and puberty. J Clin Endocrinol Metab 1983;57: 56-61.

35 Dhom G: The prepuberal and puberal growth of the adrenal (adrenarche). Beitr Pathol 1973;150:357-377.

36 Endoh A, Kristiansen SB, Casson PR, Buster JE, Hornsby PJ: The zona reticularis is the site of biosynthesis of dehydroepiandrosterone and dehydroepiandrosterone sulfate in the adult human adrenal cortex resulting from its low expression of $3 \beta$-hydroxysteroid dehydrogenase. J Clin Endocrinol Metab 1996;81:3558-3565

37 Suzuki T, Sasano H, Takeyama J, Kaneko C, Freije WA, Carr BR, Rainey WE: Developmental changes in steroidogenic enzymes in human postnatal adrenal cortex: immunohistochemical studies. Clin Endocrinol (Oxf) 2000;53:739-747.

38 Auchus RJ, Lee TC, Miller WL: Cytochrome b5 augments the 17,20-lyase activity of human P450c17 without direct electron transfer. J Biol Chem 1998;273:3158-3165.

39 Gell JS, Carr BR, Sasano H, Atkins B, Margraf L, Mason JI, Rainey WE: Adrenarche results from development of a $3 \beta$-hydroxysteroid dehydrogenase-deficient adrenal reticularis. J Clin Endocrinol Metab 1998;83: 3695-3701.
40 Merke DP, Chrousos GP, Eisenhofer G, Weise M, Keil MF, Rogol AD, Van Wyk JJ, Bornstein SR: Adrenomedullary dysplasia and hypofunction in patients with classic 21-hydroxylase deficiency. N Engl J Med 2000;343:1362-1368.

41 Hauffa BP, Kaplan SL, Grumbach MM: Dissociation between plasma adrenal androgens and cortisol in Cushing's disease and ectopic ACTH-producing tumour: relation to adrenarche. Lancet 1984;1:1373-1376.

42 Anderson DC: The adrenal androgen-stimulating hormone does not exist. Lancet 1980; 2:454-456

43 Topor LS, Asai M, Dunn J, Majzoub JA: Cortisol stimulates secretion of dehydroepiandrosterone in human adrenocortical cells through inhibition of 3 $\beta$-HSD2. J Clin Endocrinol Metab 2011;96:E31-39.

44 Biason-Lauber A, Zachmann M, Schoenle EJ: Effect of leptin on CYP17 enzymatic activities in human adrenal cells: new insight in the onset of adrenarche. Endocrinology 2000;141:1446-1454.

45 Charmandari E, Weise M, Bornstein SR, Eisenhofer G, Keil MF, Chrousos GP, Merke DP: Children with classic congenital adrenal hyperplasia have elevated serum leptin concentrations and insulin resistance: potential clinical implications. J Clin Endocrinol Metab 2002;87:2114-2120.

46 Völkl TMK, Simm D, Körner A, Kiess W, Kratzsch J, Dörr HG: Adiponectin levels are high in children with classic congenital adrenal hyperplasia due to 21-hydroxylase deficiency. Acta Paediatr 2009;98:885-891.

47 Völkl TMK, Simm D, Körner A, Rascher W, Kiess W, Kratzsch J, Dörr HG: Does an altered leptin axis play a role in obesity among children and adolescents with classic congenital adrenal hyperplasia due to 21-hydroxylase deficiency? Eur J Endocrinol 2009;160:239-247.

48 Hochberg Z: Juvenility in the context of life history theory. Arch Dis Child 2008;93:534539.

49 Charmandari E, Brook CG, Hindmarsh PC: Classic congenital adrenal hyperplasia and puberty. Eur J Endocrinol 2004;151(suppl 3):U77-U82. 